\title{
Quality of care in pediatrics: the organization of a children's hospital
}

\author{
Massimiliano Raponi \\ From 70th Congress of the Italian Society of Pediatrics, Joint National Meeting SIP, SICuPP, SITIP \\ Palermo, Italy. 11-14 June 2014
}

The Bambino Gesù Children's Hospital (OPBG) is a Research and Health Care Institute (IRCCS), organized in four sites located in Lazio Region (Roma Gianicolo, Roma S. Paolo, Palidoro, S. Marinella) and three sites located in Calabria, Basilicata and Sicily respectively. The OPBG as IRCCS, must always continue and reinforce its commitment in the integration of research and clinical practice, and transfer into the clinical practices of the knowledge produced by scientific research.

The OPBG Medical Direction is organized according to a medical and nursing multidisciplinary model and involves the interaction of a variety of professionals who work for the achievement of organizational and healthcare goals. This organization has allowed the implementation of multiple activities aimed to fully empower the staff, promote professionalism, develop awareness in relation to the needs of patients and their families and increase the focus on the continuous improvement of quality of care.

The IRCCS Bambino Gesù Children's Hospital has long since launched a series of initiatives aimed at the continuous improving in quality of care, organized according to a model of integrated clinical governance, which focuses on the whole patient and the care plan family. This approach integrates the treatment options with the patient/family's expectations in a model that imagine doctor and patient/family as cooperating partners (Family - Centered Care). In this context it is also ensured the empowerment of the patient and his family, who become a central point in decision-making and treatment processes.

Operationally, the Hospital every year prepare a Corporate Program for Continuous Improvement of Healthcare Quality, which identifies the objectives, even in terms of quantities, to be achieved in the year to ensure

Correspondence: massimiliano.raponi@opbg.net

Medical Director of Bambino Gesù Children's Hospital, Rome, 00165, Italy the continuous improvement of quality of care and monitors the achievement of targets set for the previous year.

The initiatives that are most representative of continuous promotion of healthcare quality carried out in the Hospital include: surveillance, control and prevention of adverse events; evaluating of the clinical and organizational appropriateness; production, dissemination and implementation of clinical protocols and evidence-based clinical pathway; surveillance, control and prevention of healthcare associated infections; design of clinical records that favor appropriateness and patient safety.

Published: 11 August 2014

doi:10.1186/1824-7288-40-S1-A37

Cite this article as: Raponi: Quality of care in pediatrics: the organization of a children's hospital. Italian Journal of Pediatrics 2014 40(Suppl 1):A37.

\footnotetext{
Submit your next manuscript to BioMed Central and take full advantage of:

- Convenient online submission

- Thorough peer review

- No space constraints or color figure charges

- Immediate publication on acceptance

- Inclusion in PubMed, CAS, Scopus and Google Scholar

- Research which is freely available for redistribution

Submit your manuscript at www.biomedcentral.com/submit

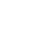

C 2014 Raponi; licensee BioMed Central Ltd. This is an Open Access article distributed under the terms of the Creative Commons Attribution License (http://creativecommons.org/licenses/by/4.0), which permits unrestricted use, distribution, and reproduction in any medium, provided the original work is properly cited. The Creative Commons Public Domain Dedication waiver (http:// creativecommons.org/publicdomain/zero/1.0/) applies to the data made available in this article, unless otherwise stated. 